России // Изд. 2-е, испр. и доп. Пушкино: ВНИИЛМ, 2013. $128 \mathrm{c}$.

32. Зенова Г.М., Степанов А.Л., Лихачева А.А., Манучарова Н.А. Практикум по биологии почв: учеб. пособие. М.: Издательство МГУ, 2002. 120 с.

\title{
RESEARCH OF MICROFLORA OF SOILS IN FOREST NURSERIES OF THE VOLOGDA REGION
}

(C) 2016

S.M. Khamitova, candidate of agricultural sciences, associate professor of the Chair of Geoecology and Engineering Geology

Yu.M. Avdeyev, candidate of agricultural sciences, associate professor of the Chair of Geoecology and Engineering Geology V.S. Snetilova, master student of the Chair of Geoecology and Engineering Geology Vologda State University, Vologda (Russia)

\begin{abstract}
Soil is a separate natural unit, its protection is a top priority issue when it is used by industry or agriculture. Urban environment is subjected to different changes because of the intensive anthropogenic influence. The soil surface of urban areas needs much attention as well as traffic influence consequences. Industrial and building sites have great impact on soil diverting its components (agrochemical and physical ones). It interferes with its important ecological function. Microbiota, biochemical parameters of the soils, its biological activity are the first to change that is why they are considered by many explorers to be the most sensitive to pollution of soil layers. Green areas play an important role for the urban population. The scientists often do not take that areas into consideration because their soils are traditionally believed not to be subjected to intensive anthropogenic influence and do not cause much of pollution and hereby are not dangerous. Meanwhile small recreational zones within cities are often influenced by industrial factors, as a result the vegetation and soils worsen though they play an important role in environmental recovery and fulfil recreational and sanitary functions. We have measured soil fungi and bacteria by a reproduction and insemination method by placing the soil suspension into dense nutrient medium.

Keywords: The soil; soil microorganisms; microbiota; soil mushrooms; actinomycetes; bacteria; phytopathogens; city green plantings; the urbanized environment; anthropogenous influence; environment; recreational territories; pollution; recreational and sanitary and hygienic functions.
\end{abstract}

\section{ФЛОРИСТИЧЕСКИЙ КОМПОНЕНТ РЕЧНОЙ ЭКОСИСТЕМЫ КАРАЛЫК}

(C) 2016

А.И. Шакуров, аспирант кафедры биологии, экологии и методики обучения Самарский государственный сочиально-педагогический университет, Самара (Россия)

Аннотация. Река Каралык - правый приток реки Большой Иргиз. Русло имеет не постоянный водоток, в летний период оно в отдельных участках пересыхает, поэтому вдоль всего русла встречаются земляные плотины, задерживающие паводковый сток. В задачу данной работы входила комплексная оценка флоры реки, т.е. характеристика систематического, экологического и биоморфологического состава. Кроме того, изучалась ресурсная значимость прибрежно-водных растений. В результате изучения флоры выявлено 53 вида прибрежно-водных растений, из них гидрофиты составляют $11,3 \%$, гигрогелофиты - 7,5\%, гелофиты - $15 \%$, гигрофиты $-30,8 \%$, гигромезофиты и мезофиты - 39,6\%. Виды растений, произрастающие в русле реки Каралык и на побережье представляют 28 родов из 24 семейств. Таксоны принадлежат к классам Liliiopsida (11 семейств) и Magnoliopsida (13 семейств). Наибольшее число видов отмечено для семейств Asteraceae, Salicaceae, Fabaceae, Poaceae, Cyperaceae, Lemnaceae, Potamogetonaceae, Polygonaceae, Typhaceae и Lamiaceae, они содержат от 7 до 2 видов, остальные 14 семейств представлены одним видом. Анализ флоры реки Каралык показал, что водная флора содержит 18 видов или $34 \%$ общего видового состава. Низкое видовое разнообразие объясняется высокой степенью эрозионных процессов, активными процессами заиления вследствие несоблюдения режима прибрежной водоохранной зоны. Низкая прозрачность воды сдерживает развитие типично водных растений.

Ключевые слова: река; русло; водоток; прибрежно-водные растения; водная флора; околоводные растения; виды растений; семейства; классы; определитель; экологические группы; гидрофиты; гелофиты и гигрогелофиты; гигрофиты; гигромезофиты; мезофиты; экологический состав; систематический состав; биоморфологический состав; хозяйственные группы растений.

Растительный компонент является важным биотическим фактором в процессах самоочищения водных экосистем. Известно, что от фильтрационной активности водных растений зависят процессы выноса ве- щества на берег и в сопредельные водоемы, перемешивание воды и прозрачность. Поскольку почти вся водная биота участвует в формировании качества воды, в сомоочищении водных экосистем, либо в регу- 
ляции этих процессов, то необходимо сохранять ее разнообразие. В связи с этим важен флористический мониторинг речных экосистем.

Первые флористические исследования рек на территории Самарской области проводились профессором К. Клаусом в бассейне р. Сок [1]. Большой вклад в изучение речной флоры внесли самарские геоботаники В.Е. Тимофеев, Е.Г. Бирюкова, В.И. Матвеев. Первая работа Владимира Ивановича Матвеева «Материалы к флоре водоемов долины реки Самары» опубликована в 1959 г., и сегодня, спустя более 55 лет, можно оценить ее важное значение для познания и в целях мониторинга прибрежно-водных и водных растений [2; 3]. В настоящее время наиболее детально изучен бассейн р. Сок $[4 ; 5]$. Исследовались особенности растительного покрова долины реки Сургут [6], изучено видовое богатство реки Чапаевки [7], однако бассейн реки Большой Иргиз долгое время не был объектом гидроботанического изучения. Есть работа А.М. Зотова, которая посвящена изучению флоры прудов Михайло-Овсянского рабопитомника, созданного в бассейне этой реки [8]. Объектом гидроботанического изучения был памятник природы «Иргизская пойма», в работах В.В. Соловьевой и Д.Е. Денисова приводятся флористические сведения [9; 10]. Данные по составу прибрежно-водной и водной флоры реки Каралык приводятся впервые.

Река Каралык - правый приток реки Большой Иргиз. Верховье реки находится в пределах возвышенности Общий Сырт. Общая протяженность реки 84 км, ее устье находится в 567 км от устья реки Большой Иргиз. Территория района сложена преимущественно юрскими глауконитовыми песками, глинами, песчаниками $[11 ; 12]$. Рельеф увалистый с интенсивным эрозионным расчленением $[13 ; 14 ; 15]$. В почвенном покрове преобладают южные черноземы. Естественная растительность представлена типчаково-ковыльными степями. Исток реки, расположенный близ села Кумраси Больше-Черниговского района, имеет характер древней балки с крутыми склонами и широким днищем. По днищу проходит вторичный размыв. Выходы грунтовых вод отмечены на расстоянии 300 м от вершины балки. Родник расположен в средней части обрывистого правого склона [16]. Его окружают заросли Phragmites australis (Cav.) Trin. Ex Steud., встречаются пятна Tussilago farfara L., Lythrum salicaria L., Artemisia procera L., Equisetum arvense L. В верхней части склон обрывистый, характерны опушки и осыпи. Задернелые поверхности заняты полынно-прутняково-ковыльными сообществами, входящими в состав структурного элемента «Ковыльные и другие степи в сопровождении степных кустарников эрозионно-аккумулятивных склонов древних балок» и «Несформировавшиеся травянистые группировки на эрозионно-аккумулятивных склонах древних балок». Многочисленные промоины, расположенные на склоне, заняты зарослями Artemisia procera L. Задернению склона препятствует чрезмерная пастьба скота.

Левый склон долины задерненный, характеризуется наличием структурного элемента «Вейниковые, костровые, пырейные и другие сообщества, образующие задернение на молодых овражных склонах». Здесь представлена разнотравно-вейниковая ассоциация.
Русло имеет незначительную глубину и не постоянный водоток, в летний период оно в отдельных участках пересыхает, поэтому вдоль всего русла встречаются земляные плотины, задерживающие паводковый сток. Вдоль русла произрастают ивняки, достигающие высоты до 15-17 метров. Под пологом ив обильна Urtica dioica L. В долине реки значительную площадь занимает пояс байрачных кустарников. В его составе преобладают Rhamnus catharctica L.и Viburnum opulus L. Характерна небольшая примесь таких древесных растений как Ulmus laevis Pall., Rosa majalis Herrm., Salix cinerea L. Сильная загущенность кустарникового яруса, обилие хмеля (Humulus lupulus L.), препятствуют развитию травянистого покрова. Лугово-лесное разнотравье в виде узкого пояса окаймляет кустарниковые заросли с периферии. В его составе произрастают Saguvisorba officinalis L. Convallaria majalis L., Filipendula ulmaria (L.) Maxim., Geum urbanum L., Fragaria viridis L., Vicia sepium L. и другие. На пониженных участках долины и у подножия склонов широкое распространение имеют заросли Artemisia procera L. Она образует первый ярус, во втором преобладает Calamagrostis epigeios (L.) Roth, остальные виды имеют незначительное обилие.

При изучении и анализе прибрежно-водной флоры приняты методические подходы В.Г. Папченкова и В.В. Соловьевой [17], т.е. учитывалась не только водная флора (гидрофиты, гелофиты и гигрогелофиты), а флора водотока в целом, с включением в нее околоводных видов растений (гигрофитов, гигромезофитов и мезофитов). В задачу данной работы входила комплексная оценка флоры реки Каралык, т.е. характеристика систематического, экологического и биоморфологического состава. Кроме того, изучалась ресурсная значимость прибрежно-водных растений.

Определение растений проводилось с использованием «Флоры средней полосы Европейской части СССР» [18] и «Определителя растений Среднего Поволжья» [19]. Видовые научные названия растений даны согласно сводке С.К. Черепанова [20].

В результате изучения флоры выявлено 53 вида прибрежно-водных растений, из них гидрофиты составляют $11,3 \%$, гигрогелофиты - 7,5\%, гелофиты $15 \%$, гигрофиты - 30,8\%, гигромезофиты и мезофиты - 39,6\% (табл. 1). Содержание понятий перечисленных экологических групп принимается в трактовке В.В. Соловьевой и А.Г. Лапирова [21].

«Гидрофиты - это истинно-водные растения, которые для нормального прохождения своего жизненного цикла требуют постоянного контакта вегетативного тела с водной средой. Различают свободно плавающие на поверхности воды или в ее толще, а также погруженные укореняющиеся растения, с плавающими листьями или без них. Гидрофиты могут образовывать фитоценозы на всех доступных водным макрофитам глубинах, чаще всего они обычны в пределах от 0,5 до 3 м. Некоторые гидрофиты могут в угнетенном состоянии непродолжительное время существовать и на обсохших мелководьях. У этих видов иногда развиваются наземные формы, но для прохождения всего жизненного цикла им необходима водная среда» [21, с. 8] К гидрофитам во флоре изучаемой реки относятся Ceratophyllum demersum L., 
Lemna minor L., Nuphar lutea L., Spirodela polyrhisa (L.) Schleid, Potamogeton perfoliatus L., P. pectinatus L.

«Гелофиты - это воздушно-водные укореняющиеся растения, вегетативное тело которых расположено как в воде, так и над ее поверхностью. Растения данной экологической группы занимают прибрежные мелководья с глубиной до 1(2) м. По высоте побегов они делятся на высокотравные - средняя высота побегов 180-250 см и низкотравные - 60-100 см. Наиболее глубоко проникают высокотравные гелофиты; низкотравные обычны на глубинах до 0,5 м, однако некоторые из них могут проникать и на большие глубины, образуя погруженные формы с лентовидными листьями. Обычно базальные части надземных побегов гелофитов частично погружены в воду, однако эти растения способны переносить длительное обсыхание в период вегетации» [21, с. 10]. Из гелофитов во флоре реки Каралык отмечены Alisma plantago-aquatica L., Butomus umbellatus L., Phragmites australis (Cav.) Trin. ex Steud., Scirpus tabernaemontani Gmel., S. lacustris L., Sparganium erectum L., Typha angustifolia L., T. latifolia L.

«Гигрогелофиты - растения уреза воды, типичными местообитаниями которых являются низкие уровни береговой зоны затопления, зона контакта берега и водного тела (т.е. уреза воды) и прибрежные отмели с глубиной до 20 (40) см, многие из них типичны для окраин озерных сплавин. Нередко, укореняясь на топких берегах, они наплывают на открытую воду» [21, с. 11]. Из гигрогелофитов встречены Agrostis stolonifera L., Bolboschoenus kozhevnikovii (Liv.) A.E. Kochevnikov, Eleocharis palustris (L.) Roem et Schult., Lythrum salicaria L.

«Гигрофиты - заходящие в воду травянистые и древесные береговые растения, закономерно встречающиеся на водопокрытом грунте. Обычно они обитают в условиях избыточной влажности грунта и высокой влажности воздуха, занимая средние уровни береговой зоны затопления, но довольно часто заходят в воду у низких топких берегов. В последнем случае они могут входить в состав сообществ гигрогелофитов и гелофитов. К древесным гигрофитам относятся многие виды ив, которые часто обрамляют берега водоемов и водотоков, нередко растут и в воде» [21, с. 11]. К экологической группе гигрофитов во флоре реки Каралык относятся Bidens cernua L., B. frondosa L., B. tripartita L., Carex pseudocyperus L., Echinochloa crusgalli (L.) Beauv., Epilobium palustre L., E. hyrsutum L., Juncus gerardii Loisel, Lycopus europeus L., Salix alba L., S. acutifolia Willd., S. cinerea L., S. fragilis L., S. pentandra L., Populus nigra L., Solanum dulcamara L., Stachys palustris L.

«Гигромезо- и мезофиты характерны для высоких уровней береговой зоны затопления и зоны заплеска. Гигромезофиты в водной среде встречаются редко. Они занимают влажнолуговое и сыролуговое местообитания, а мезофиты встречаются в сухолуговых и свежелуговых условиях. Мезофиты экологически пластичны, при повышенной влажности проявляют гигроморфные черты. Они имеют умеренно развитые корневые системы разного типа, листья с негустой сетью жилок, дифференцированным мезофиллом и хорошо развитой системой межклетников. По физиологическим показателям водного режима мезофиты характеризуются умеренными величинами осмотического давления, содержания воды в листьях, предельного водного дефицита. Величина транспирации зависит от степени освещенности» [21, с. 12] К гигромезофитам и мезофитам побережий реки Каралык относятся Artemisia procera L., Calystegia sepium (L.) R. Br., Chenopodium glaucum L., Echinocistis lobata (Michx.) Torr. et Grey., Elytrigia repens (L.) Nevski, Inula britannica L., Leontodon autumnalis L., Medicago lupulina L., Melilotus officinais (L.) Lam., Persicaria lapathifolia (L.) S.F. Gray., Plantago intermedia D.C., Poa angustifolia L., Potentilla anserina L., Ranunculus repens L., Rumex confertus Willd., $R$. stenophyllus Ledeb., Stachys recta L., Trifolium hybridum L., T. pratense L., T. repens (L.) C. Presl, Urtica dioica L., Xanthium strumarium $\mathrm{L}$.

Таблица 1 - Экологический спектр флоры реки Каралык

\begin{tabular}{|l|c|c|}
\hline \multirow{2}{*}{ Экологическая группа } & \multicolumn{2}{|c|}{ Число видов } \\
\cline { 2 - 3 } & абсолютное & в \% \\
\hline Гидрофиты & 6 & 11,3 \\
\hline Гелофиты & 8 & 15 \\
\hline Гигрогелофиты & 4 & 7,5 \\
\hline Гигрофиты & 16 & 30,8 \\
\hline Гигромезофиты и мезофиты & 21 & 39,6 \\
\hline
\end{tabular}

Виды растений, произрастающие в русле реки Каралык и на побережье представляют 28 родов из 24 семейств. Таксоны принадлежат к классам Liliiopsida (11 семейств) и Magnoliopsida (13 семейств). Наибольшее число видов отмечено для семейств Asteraceae, Salicaceae, Fabaceae, Poaceae, Cyperaceae, Lemnaceae, Potamogetonaceae, Polygonaceae, Typhaceae и Lamiaceae, они содержат от 7 до 2 видов, остальные 14 семейств представлены одним видом (табл. 2).

Таблица 2 - Ведущие семейства флоры реки Каралык

\begin{tabular}{|l|c|c|}
\hline Название семейства & Число родов & Число видов \\
\hline Asteraceae & 7 & 7 \\
\hline Salicaceae & 2 & 6 \\
\hline Fabaceae & 3 & 5 \\
\hline Lamiaceae & 4 & 4 \\
\hline Cyperaceae & 4 & 4 \\
\hline Poaceae & 4 & 4 \\
\hline Potamogetonaceae & 1 & 2 \\
\hline Typhaceae & 1 & 2 \\
\hline Lemnaceae & 2 & 2 \\
\hline Polygonaceae & 2 & 2 \\
\hline
\end{tabular}

Жизненные формы растений изученной флоры представлены 6 видами древесно-кустарниковых растений, 2 - полукустарниками, 7 - видами малолетников и 39 - видами многолетних травянистых растений (табл. 3).

Анализ хозяйственных групп флоры показал, что в ее составе 22 вида растений, имеющих кормовое значение, 19 лекарственных, 11 медоносных видов растений (табл. 4). Кроме того, отмечены декоративные, жирно- и эфирно-масличные виды растений, мелиоративные, технические, плетеночные, пищевые, пыльценосные и сорные растения. Так, например, на 
03.02 .00 - общая биология

побережье реки широкое распространение и высокое обилие имеют такие лекарственные растения как череда трехраздельная, зюзник европейский, подорожник большой и другие. Ценными медоносами являются виды ив, дербенник иволистный, донник лекарственный, лапчатка гусиная, кульбаба осенняя и другие. Кормовые растения представлены клевером ползучим, луговым, гибридным, мятликом узколистным, полевицей побегообразующей.

Таблица 3 - Жизненные формы растений флоры реки Каралык

\begin{tabular}{|l|c|c|}
\hline \multicolumn{1}{|c|}{ Морфологическая группа } & Число видов & в \% \\
\hline Древесно-кустарниковые & 6 & 9,4 \\
\hline Полукустарники & 2 & 3,8 \\
\hline Травы & 46 & 86,8 \\
\hline из них: & 7 & \\
\hline - одно-двулетники & 39 & \\
\hline - многолетники & 18 & \\
\hline - корневищные & 6 & \\
\hline - стержнекорневые & 1 & \\
\hline - корнеотпрысковые & 1 & \\
\hline - кистекорневые & 3 & \\
\hline - листецовые & 2 & \\
\hline - клубнекорневищные & & \\
\hline
\end{tabular}

Таблица 4 - Хозяйственное значение растений реки Каралык

\begin{tabular}{|l|c|}
\hline \multicolumn{1}{|c|}{ Хозяйственная группа } & Число видов \\
\hline Кормовое & 22 \\
\hline Лекарственное & 19 \\
\hline Медоносное & 11 \\
\hline Эфирномасличное & 9 \\
\hline Жирномасличные & 7 \\
\hline Техническое & 6 \\
\hline Мелиоративное & 6 \\
\hline Плетеночное & 5 \\
\hline Декоративное & 4 \\
\hline Пыльценосное & 4 \\
\hline Пищевое & 3 \\
\hline Сорное & 2 \\
\hline
\end{tabular}

В целом, анализ флоры реки Каралык показал, что водная флора содержит 18 видов или $34 \%$ от общего видового состава. Низкое видовое разнообразие объясняется высокой степенью эрозионных процессов и активными процессами заиления вследствие не соблюдения режима прибрежной водоохранной зоны. Низкая прозрачность воды сдерживает развитие типично водных растений.

\section{СПИСОК ЛИТЕРАТУРЫ:}

1. Клаус К. Флоры местные приволжских стран. СПб., 1852. $312 \mathrm{c.}$

2. Матвеев В.И. Материалы к флоре водоемов долины р. Самары // Ученые записки Куйбышев. пед. ин-та. Куйбышев: КГПИ. 1959. Вып. 23. С. 55-72.

3. Матвеев В.И. Флора водоемов Средней Волги и ее притоков // Ботаника и сельское хозяйство. Куйбышев, 1969. С. 30-78.
Флористический компонент речной экосистемы Каралык

4. Выхристюк Л.А., Зинченко Т.Д., Лаптева Е.В. Комплексная оценка экологического состояния равнинной р. Сок (Бассейн нижней Волги) // Известия Самарского научного центра РАН. 2010. Т. 12. № 1. C. 186-197.

5. Лапов И.В., Соловьева В.В. Сравнительный анализ флоры р. Сок и ее притоков // Сибирский педагогический журнал. 2013. № 4. С. 165-168.

6. Лысенко T.М., Митрошенкова А.Е. Особенности растительного покрова долины реки Сургут (Самарская область) // Малые реки - современное экологическое состояние, актуальные проблемы: Междунар. научная конф. (Россия, Тольятти, 23-27 апреля 2001 г.). Тольятти: ИЭВБ РАН, 2001. С. 128.

7. Соловьева В.В., Денисов Д.Е., Сенатор С.А. Фиторазнообразие реки Чапаевки // Фиторазнообразие Восточной Европы. 2006. № 1. С. 111-122.

8. Зотов А.М. Флора и растительность прудов Михайло-Овсянского рыбопитомника // Морфология и динамика растительного покрова: Науч. тр. Куйб. гос. пед. ин-та. 1977. Т. 207. Вып. 6. С. 77-83.

9. Денисов Д.Е., Соловьева В.В. Бассейн реки Большой Иргиз: история изучения биоразнообразия и перспективы гидроботанического мониторинга // Степи Северной Евразии: Матер. IV Междунар. симпозиума. Оренбург: ИПК «Газпромпечать», 2006. C. 230-233.

10. Соловьева В.В., Денисов Д.Е. Гидроботаническое изучение памятника природы «Иргизская пойма»// Гидроботаника-2005: Материалы VI Всероссийской конференции по водным макрофитам (п. Борок, 11-16 октября 2005 г.). Рыбинск: ОАО «Рыбинский дом печати», 2006. С. 354-356.

11. Физико-географическое районирование Среднего Поволжья / под ред. А.В. Ступишина. Казань: Изд-во Казан. ун-та, 1971.

12. Захаров А.С. Рельеф // Природа Куйбышевской области / сост. М.С. Горелов, В.И. Матвеев, А.А. Устинова. Куйбышев: Кн. изд-во, 1990. С. 45-76.

13. Мильков Ф.Н. Средняя полоса Европейской части СССР. М.: Географгиз, 1961. 216 с.

14. Мильков Ф.Н. Региональные особенности и зонально-морфологические типы речных долин Среднерусской лесостепи // Долинно-речные ландшафты Среднерусской лесостепи. Воронеж, 1987.С. 34-42.

15. Равнины Европейской части СССР. М.: Наука, 1974. $235 \mathrm{c}$.

16. Бирюкова Е.Г. Растительный покров речных истоков // Сложение и динамика растительного покрова: Межвуз. сборник научных трудов. Куйбышев, 1983. C. 41-49.

17. Папченков В.Г., Соловьева В.В. Флора прудов Среднего Поволжья // Самарская лука. Бюллетень. 1993. № 4. С. 172-190.

18. Флора средней полосы Европейской части СССР / под ред. П.Ф. Маевского. Л.: Колос, 1964. $880 \mathrm{c}$.

19. Определитель растений Среднего Поволжья / под ред. П.П. Благовещенского. Л.: Наука, 1984. 392 с.

20. Черепанов С.К. Сосудистые растения России и сопредельных государств. СПб., 1995. 990 с.

21. Соловьева В.В., Лапиров А.Г. Гидроботаника: учебное пособие. Самара: ПГСГА, 2013. 354 с. 


\section{FLORISTIC COMPONENT OF ECOSYSTEM OF THE KARALYK RIVER}

A.I. Shakurov, postgraduate student of the Chair of Biology, Ecology and Methods of Teaching Samara State University of Social Sciences and Education, Samara (Russia)

Abstract. Karalyk River - the right tributary of the river Big Irgiz. The channel has no permanent watercourse, in summer it occasionally dries up, so along the entire course meet earthen dams, retarding flood flows. The task of this work included a comprehensive assessment of the flora of the river, the characteristics of systematic, ecological and biomorphological composition. Furthermore, the authors investigated the resource value of the riparian-aquatic plants. A study of the flora revealed 53 species of semi-aquatic plants, hydrophytes amount to $11,3 \%$, hygrogelophytes $7,5 \%$, galofity (15\%), hygrophytes $-30,8 \%$, hygromesophyte and mesophytae of $39,6 \%$. The types of plants growing in the bed of the river Karalic and the coast represented by 28 genera from 24 families. The taxa belong to the classes Liliiopsida (11 families) and are represented by a (13 families). The greatest number of species observed for the Asteraceae Salicaceae, Fabaceae, Poaceae, Cyperaceae, Lemnaceae, Potamogetonaceae, Polygonaceae, Lamiaceae, and Typhaceae, they contain from 7 to 2 species, the remaining 14 families represented by one species. Analysis of the flora of the river Karalic showed that the aquatic flora contains 18 species or $34 \%$ of the total species composition. Low species diversity is due to the high degree of erosion processes, active processes of sedimentation as a result of failure of coastal protection zones. Low water clarity inhibits the development of the typical aquatic plants.

Keywords: Karalyk river; track; watercourse; coastal aquatic plants; aquatic; wetland plants; plant species; family; classes; determinant; environmental groups; hydrophytes; grass helophytes and gigrogelofity; hygrophytes; gigromezofity; mesophytes; ecological structure; taxonomic composition; biomorphological composition; economic groups of plants. 